\title{
Дренування рідинних скупчень заочеревинного простору при лікуванні гострого некротичного панкреатиту
}

\begin{abstract}
Гострий панкреатит - одне з найтяжчих ургентних хірургічних захворювань. У близько чверті хворих розвиваються його некротичні форми з високим рівнем летальності. Тому нашою метою було покращення результатів хірургічного лікування хворих із гнійно-септичними ускладненнями некротичного панкреатиту шляхом застосування мініінвазивних (щадних) операційних втручань. Проведено аналіз комплексного лікування 37 хворих на гострий некротичний панкреатит у період гнійно-септичних ускладнень із поширенням гнійних періпанкреатичних запливів у заочеревинний простір. Після верифікації локалізації поширення запливу під контролем ультразвукового апарата методом “вільної руки” вводили троакар. Відстань до вогнища складала від 4 до 12 см. Виконували дренування рідинного утвору, гнійника з введенням у його порожнину дренажної трубки “нелотон” діаметром 12 Fr. При неефективності дренажної функції даного діаметра в 17 (46 \%) пацієнтів вводили дренаж діаметром 20 Fr. При використанні даної методики спостерігали покращення її евакуаторної спроможності з відходженням секвестрів великого розміру. Це дозволило зменшити прояви інтоксикаційного синдрому, синдрому системної запальної відповіді та запобігти повторним лапаротомним операційним втручанням.
\end{abstract}

Ключові слова: некротичний панкреатит; дренування рідинних скупчень.

Гострий панкреатит (ГП) - одне з найтяжчих ургентних хірургічних захворювань. У близько чверті хворих розвиваються його некротичні форми $[1-3,6]$.

ГП - поліетіологічне захворювання, вирізняється тяжкістю перебігу, тривалістю лікування, суттєвими матеріальними затратами. В 25 \% випадків клінічний перебіг ГП супроводжується розвитком гнійно-септичних ускладнень із формуванням рідинних утворів парапанкреатичних та параколярних флегмон $[1,4]$. Летальність при гострому деструктивному панкреатиті як в Україні, так і поза ії межами, сягає в середньому $20 \%$, а при вкрай тяжкому перебігу цей показник зростає в рази $[1,3,7]$.

При застосуванні класичних хірургічних методики лікування даної групи пацієнтів не завжди досягають бажані результати, а тяжкий стан хворого часто стоїть на заваді їхнього проведення. Тому на сьогодні актуальними залишаються мініінвазивні (щадні) операційні втручання, котрі зменшують вплив операційної травми, дозволяють достатньо адекватно провести санацію вогнищ ураження, запобігши контамінації черевної порожнини інфікованим панкреатичним вмістом [5-7].

Мета роботи: покращення результатів хірургічного лікування хворих з гнійно-септичними ускладненнями некротичного панкреатиту шляхом застосування мініінвазивних (щадних) операційних втручань.

Проведено аналіз комплексного лікування 37 хворих віком 19-78 років на гострий некротичний панкреатит в період гнійно-септичних ускладнень 3 поширенням гнійних періпанкреатичних запливів у позаочеревинний простір, серед них - 14 жінок, 23 пацієнта чоловічої статі. Усі хворі знаходились на стаціонарному лікуванні в хірургічному відділенні Тернопільської університетської лікарні впродовж останніх п'яти років. У 12 (32 \%) пацієнтів на момент госпіталізації вже було проведено дренування черевної порожнини, з них у половини - в поєднанні із великою сальниковою сумкою з приводу гострого ферментативного перитоніту на попередніх етапах лікування в районних стаціонарах.

Верифікацію діагнозу здійснювали на основі клінічних проявів, даних лабораторних досліджень, інструментальних методів обстеження. В усіх пацієнтів інструментальну діагностику поширення ураження підшлункової залози та парапанкреатичних зрушень проводили за допомогою сонографічної діагностики, а у 30 (81 \%) - проводилась комп’ютерна томографія з внутрішньовенним контрастним підсиленням.

Після верифікації локалізації поширеності запливу в позаочеревинний простір на стаціонарному ультразвуковому апараті та визначення оптимальної точки вколу, хворого перевозили в операційну. Під місцевим знеболенням під контролем ультразвукового апарата методом “вільної руки” вводили троакар. Відстань до вогнища складала від 4 до 12 см. Виконували дренування рідинного утвору, гнійника з введенням в його порожнину дренажної трубки “нелотон” діаметром 12 Fr. 
Проводили евакуацію вмісту з визначенням рівня в ньому амілази, забір матеріалу на бактеріологічний посів із визначенням чутливості до антибіотиків та цитологічне дослідження. Глибину введення дренажної трубки визначали шляхом порівняння довжини її з ідентичною трубкою. Правильність постановки дренажу оцінювали за характером отриманого вмісту, сонографічно та ретгенологічно з допомогою фістулографії, з використанням водорозчинного контрасту.

Відсутність патологічних виділень із дренажних трубок черевної порожнини у хворих раніше прооперованих в районних лікарнях дозволило видалити їх на 1-2 добу після дренування позаочеревинного простору та проведеного сонографічного контролю.

У 17 (46 \%) хворих із клінічними, сонографічними, лабораторними ознаками неадекватного дренування вогнищ на 5 - 6 добу проводили введення в його порожнину трубки більшого діаметру 20 Fr, використовуючи наявну дренажну трубку як провідник. Це дозволило евакуювати секвестри значного розміру та якісніше санувати гнійне вогнище.

Залежно від об'єму ураження підшлункової залози, поширення явищ деструкції в заочеревинному просторі 17 (46 \%) хворим проводили правобічне, 14 (38 \%) - лівобічне, а 6 (16 \%) - двобічне дренування.

Після постановки дренажної трубки діаметром 20 Fr, у 9 (53 \%) хворих спостерігали гнійні виділення з незначними домішками геморагічного характеру. 3 метою запобігання кровотечі 3

\section{СПИСОК ЛІТЕРАТУРИ}

1. Особенности патогенетического подхода к лечению острого некротического панкреатита / А. И. Дронов, И. А. Ковальская, В. Ю. Уваров, А. И. Горлач // Украинский журнал хирургии. 2013. - № 22 (3). - С. 145-149.

2. Конфигурация некроза поджелудочной железы и дифференцированное лечение острого панкреатита / Т. Г. Дюжева, Е. В. Джус, А. В. Шефер [и др.] // Анналы хирургической гепатологии. - 2013. - № 18 (1). - С. 92-102.

3. Nakamoto D. A. Emergent ultrasound interventions / D. A. Nakamoto, J. R. Haaga // Radiologic Clinics of North America. - 2004. - Vol. 42 (2). - P. 114-123.

4. Can fluid resuscitation prevent pancreatic necrosis in severe порожнини гнійника, протягом першої доби використовували дренаж в пасивному режимі, без активних промивань. Необхідності в додатковій корекціях лікування геморагічних ускладнень 3 приводу наявних геморагічних домішок у виділеннях дренажу порожнини гнійника не було.

У 17 (46 \% ) пацієнтів з використанням дренажної трубки діаметром 20 Fr відзначали покращення евакуаторної спроможності вогнищ деструкції з відходженням секвестрів великого розміру. Найбільший зафіксований нами секвестр був довжиною 6, 5 см. Комплексне консервативне лікування гострого некротичного панкреатиту, ускладненого гнійно-септичними вогнищами заочеревинного простору, дозволило зменшити прояви інтоксикаційного синдрому, синдрому системної запальної відповіді. Це підтверджували як покращення загального стану пацієнтів, так і лабораторні показники аналізу крові та зниження чи нормалізація показника С-реактивного білка, прокальцитоніну, що дозволило запобігти повторним лапаротомним операційним втручанням та пришвидшити одужання хворих. Дана методика дозволяла на 10-12 добу виписувати хворих для подальшого лікування в умовах хірургічних стаціонарів районних лікарень.

Комплексне лікування гострого некротичного панкреатиту в поєднанні із застосуванням пункційно-дренуючих втручань під сонографічним контролем, дозволило досягти кращого дренуючого ефекту гнійних вогнищ заочеревинного простору та зменшити прояви інтоксикаційного синдрому, синдрому системної запальної відповіді чи сепсису. acute pancreatitis? / A. Brown, J. D. Baillargeon, M. D. Hughes, P. A. Banks // Pancreatology. - 2002. - Vol. 2 (2). P. 104-107.

5. Manzelli A. Groove pancreatitis: a mini-series report and review of the literature / A. Manzelli, A. Petrou, A. Lazzaro // JOP. J Pancreas (Online). - 2011. - Vol. 12 (3). - P. 230-233.

6. Necrotizing pancreatitis: a review of multidisciplinary management / A. Sabo, N. Goussous, N. Sardana // JOP. Journal of the Pancreas (Online). - 2015. - Vol. 16 (2) - - P. 125-35.

7. Zerem E. Treatment of severe acute pancreatitis and its complications / E. Zerem // World J. Gastroenterol. - 2014. Vol. 20 (38). - P. 13879-13892. 


\section{ПОВІДОМЛЕННЯ}

\section{REFERENCES}

1. Dronov, A.I., Kovalskaya, I.A., Uvarov, V.Yu., \& Gorlach, A.I. (2013). Osobennosti patogeneticheskogo podkhoda $\mathrm{k}$ lecheniyu ostrogo nekroticheskogo pankreatita. Ukrainskiy zhurnal khirurhii - Ukrainian Journal of Surgery, 22 (3), 145149 [in Russian].

2. Dyuzheva, T.G., Dzhus, Ye.V., Shefer, A.V., Akhaladze, G.G., Chevokin, A.Yu., Kotovskiy, A.Ye., ..., \& Shono, N.I. (2013). Alperin E.I Konfiguratsiya nekroza podzheludochnoy zhelezy i differentsirovannoye lecheniye ostrogo pankreatita [The configuration of pancreatic necrosis and the differentiated treatment of acute pancreatitis]. Annaly khirurgicheskoy gepatologii - Annals of Surgical Hepatology, 18 (1), 92-102 [in Russian].

3. Nakamoto, D.A., \& Haaga, J.R. (2004). Emergent ultrasound interventions. Radiologic Clinics of North America, 42 (2), 114-123. 4. Brown, A., Baillargeon, J.D., Hughes, M.D., \& Banks, P.A (2002). Can fluid resuscitation prevent pancreatic necrosis in severe acute pancreatitis? Pancreatology, 2 (2), 104-107.

5. Manzelli, A., Petrou, A., \& Lazzaro, A. (2011). Groove pancreatitis: a mini-series report and review of the literature. JOP. $J$ Pancreas (Online), 12 (3), 230-233.

6. Sabo, A., Goussous, N., Sardana, N., Patel, S., \& Cunningham, S.C. Necrotizing pancreatitis: a review of multidisciplinary management. JOP. Journal of the Pancreas (Online), 16 (2), 125135.

7. Zerem, E. (2014). Treatment of severe acute pancreatitis and its complications. World J. Gastroenterol., 20 (38), 13879-13892.

Отримано 25.10.2019

\section{DRAINAGE OF RETROPERITONEAL LIQUID CLUSTERS AT ACUTE NECROTIZING PANCREATITIS MANAGEMENT}

Acute pancreatitis is one of the most severe urgent surgical diseases. Its necrotic forms with a high mortality rate develop in about a quarter of patients with this disease. Therefore, our aim was to improve the results of surgical treatment of patients with purulent-septic complications of necrotizing pancreatitis by applying of minimally-invasive surgical interventions. The analysis of complex treatment of 37 patients with acute necrotizing pancreatitis during the period of purulent-septic complications with the spread of purulent peripancreatic clusters to the retroperitoneum was performed. After verifying the localization of clusters spread a trocar was inserted under the control of the ultrasound machine by the "free hand" method. The distance to the cluster was from 4 to $12 \mathrm{~cm}$. The drainage of fluid formation, abscess with introduction into its cavity of a drainage tube "Neloton" with a diameter of 12 Fr was performed. In case of ineffectiveness of the drainage function of this diameter, 17 (46\%) patients were drained with tube diameter of 20 Fr. The improvement of its evacuation capacity with the removal of large size sequesters was noted at using of this technique. This allowed to reduce the manifestations of the intoxication syndrome, the systemic inflammatory response syndrome and to prevent repeat laparotomy.

Key words: necrotizing pancreatitis; drainage of retroperitoneal clusters.

И. И. СМАЧИЛО, А. Д. БЕДЕНЮК, И. В. СМАЧИЛО, В. Б. ДОБРОРОДНИЙ, Ю. М. ФУТУЙМА

Тернопольский национальный медицинский университет имени И. Я. Горбачевского

\section{ДРЕНИРОВАНИЕ ЖИДКОСТНЫХ СКОПЛЕНИЙ ЗАБРЮШИННОГО ПРОСТРАНСТВА ПРИ ЛЕЧЕНИИ ОСТРОГО НЕКРОТИЧЕСКОГО ПАНКРЕАТИТА}

Острый панкреатит относится к одним из самых тяжелых ургентных хирургических заболеваний. В около четверти больных такой болезнью развиваются его некротические формы с высоким уровнем летальности. Поэтому нашей целью было улучшение результатов хирургического лечения больных с гнойно-септическими осложнениями некротического панкреатита путем применения миниинвазивных (щадящих) операционных вмешательств. Проведен анализ комплексного лечения 37 больных острым некротическим панкреатитом в период гнойно-септических осложнений с распространением гнойных перипанкреатических заплывов в забрюшинное пространство. После верификации локализации распространенности заплыва под контролем ультразвукового аппарата методом “свободной руки” вводили троакар. Расстояние к очагу составляло от 4 до 12 см. Выполняли дренирование жидкостного образования, гнойника с введением в его полость дренажной трубки “Нелотон” диаметром 12 Fr. При неэффективности дренажной функции данного диаметра 17 (46 \%) пациентам вводили дренаж диаметром 20 Fr. При использовании данной методики отмечали улучшение эвакуаторной ее возможности с отхождением секвестров большого размера. Это позволило уменьшить проявления интоксикационного синдрома, синдрома системного воспалительного ответа и предотвратить повторные лапаротомные операционные вмешательства.

Ключевые слова: некротический панкреатит; дренирование жидкостных скоплений. 